\title{
StanisŁaw WójCiK, PERSONALISTYCZNA MYŚL POLITYCZNA, LubLIN 2020, ss. 75
}

Obserwacja życia społeczno-politycznego w naszym kraju wskazuje, jak w praktyce trudno jest zobiektywizować kryteria pozwalające jednoznacznie określać działania polityczne jako godne lub niegodne. Istnieje rozległy obszar działań politycznych, których godność lub niegodność ocenia się w zasadzie tylko z punktu widzenia określonej koncepcji politycznej, a nawet partyjnej, z uwzględnieniem własnego lub społecznego interesu. Można mówić o zanikaniu godności jako wartości w polityce. Polityka nie może jednak stanowić alternatywy dla wartości moralnych, a zwłaszcza dla godności osoby ludzkiej. Autentyczną demokrację można zbudować tylko na gruncie obiektywnych i niezmiennych wartości, wśród których godność osoby ludzkiej, jej wolność i życie w prawdzie zajmują centralne miejsce.

Kościół katolicki w swoim nauczaniu społecznym podkreśla, że prawa człowieka, których poszanowanie jest częścią integralną każdej kultury, są uniwersalne i niezmienne. Ich źródłem jest równa godność przysługująca każdemu człowiekowi. Życie ludzkie, aby osiągnąć swoją pełnię, potrzebuje odniesienia nie do wartości ulotnych i powierzchownych, ale trwałych i głębokich. Cała działalność polityczna powinna być z człowieka, przez człowieka i dla człowieka. Nie może ona popaść w antynomię z samym człowieczeństwem. Racją bytu wszelkiej polityki jest służba dla człowieka, pełne troski i odpowiedzialności zaangażowanie się $\mathrm{w}$ istotne sprawy i zadania jego ziemskiego bytowania w wymiarach społecznych. Poszanowanie osoby ludzkiej wykracza poza sferę moralności indywidualnej i staje się podstawowym kryterium, niejako filarem społeczeństwa, które jest wewnętrznie ukierunkowane na osoby.

$\mathrm{W}$ przemówieniu wygłoszonym $\mathrm{w}$ parlamencie $\mathrm{W}$ Warszawie 11 czerwca 1999 r. Jan Paweł II podkreślił, że troska o dobro wspólne powinna być realizowana przez wszystkich obywateli i powinna przejawiać się we wszystkich sektorach życia społecznego. W szczególny sposób troska o dobro wspólne jest wymagana w dziedzinie polityki. Wykonywanie władzy politycznej, czy to we wspólnocie, czy to w instytucjach 
reprezentujących państwo, powinno być ofiarną służbą człowiekowi i społeczeństwu. Nie może być ono szukaniem własnych czy grupowych korzyści, z pominięciem dobra wspólnego całego narodu. Autonomia właściwa życiu wspólnoty politycznej nie oznacza, że może być ona rozumiana jako niezależność od zasad etycznych. Także państwa pluralistyczne nie mogą zrezygnować z norm etycznych w życiu publicznym. Papież życzył polskim politykom i osobom zaangażowanym w życie publiczne, by budowali takie państwo, które otacza szczególną troską rodzinę, życie ludzkie, wychowanie młodego pokolenia, ale i respektuje prawo do pracy, widzi istotne sprawy całego narodu oraz jest wrażliwe na potrzeby konkretnego człowieka, szczególnie ubogiego i słabego.

W nauczaniu Kościoła katolickiego podkreśla się nierozerwalny związek demokracji z prawdą, z wartościami, z prawami człowieka. Bez tej koniunkcji nie jest możliwa autentyczna demokracja, a nawet taki system może przekształcać się w coś, co jest jej przeciwieństwem. Jeżeli w dziedzinie polityki nie są przestrzegane m.in. takie zasady jak: uczciwość w kontaktach między rządzącymi a rządzonymi, jawność w administracji publicznej, bezstronność w rozstrzyganiu spraw publicznych, poszanowanie praw przeciwników politycznych, ochrona praw ludzi oskarżonych w procesach i sądach doraźnych, sprawiedliwe i uczciwe wykorzystywanie pieniędzy publicznych, odrzucenie niegodziwych metod zdobywania, utrzymywania i poszerzania władzy za wszelką cenę, wówczas zanika sam fundament politycznego współistnienia, a całe życie społeczne jest wystawione na ryzyko, zagrożenie i rozkład. Porządek społeczny nie opiera się wówczas na podłożu etycznym. Oddzielenie polityki i życia społeczno-gospodarczego od etyki jest jednak zawsze niebezpieczne, podobnie jak i wykorzystywanie religii, aby budować kapitał wyborczy.

Wiele z kwestii dotyczących relacji polityki i moralności podejmuje prof. Stanisław Wójcik w swoim opracowaniu pt. Personalistyczna myśl polityczna. Całość opracowania składa się z sześciu rozdziałów: rozdział I: Państwo w ujęciu personalizmu; rozdział II: Samorzad terytorialny w perspektywie personalizmu; rozdział III: Duchowa konstytucja świata; rozdział IV: Religia, chrześcijaństwo, prawo, państwo; rozdział V: Znaczenie Kościoła katolickiego dla bezpieczeństwa państwa III RP; rozdział VI: Wspótczesne próby opisania narodu i rodziny. Zamiast Zakończenia Autor umieszcza krótki tekst zatytułowany O prawdę i dobro wspólne w państwie.

W opracowaniu liczącym kilkadziesiąt stron prof. Wójcik podejmuje bardzo ważne zagadnienia. $W$ rozdziale pierwszym i drugim szkicuje 
personalistyczną koncepcję państwa oraz samorządu terytorialnego, wskazując na nowe możliwości reformowania ustroju, funkcjonowania państwa, samorządu terytorialnego i postaw osobowych obywateli. Z tych rozważań wyłania się scenariusz nowej drogi dla państwa i społeczeństwa, promującej ideę oraz wiedzę humanistyczną i etyczną. Wskazuje przy tym na wady dominującego we współczesnym świecie zachodnim i częściowo w Polsce nurtu liberalizmu. Państwo i prawo są legitymizowane nie tylko przez demokratyczną większość, ale i przez konieczne minimum aksjologiczne (moralność).

Autor pisze: „Polityka współczesna tak w praktyce, jak i w teorii zdaje się istnieć daleko od podstawowych wartości osobowych, np. etyki. W polityce moralność po prostu przestaje istnieć. Jest tu wielkie zadanie stojące przed nauką. Musimy spersonalizować politykę, przepoić ją etyką, wyrugować z niej mentalność egoizmu i brutalności. Uważam, że bez zastosowania i rozwoju systemu personalistycznego nie zhumanizujemy życia publicznego i pozostaniemy rozdarci między bytem chrześcijańskim a światem politycznym. Jak dotychczas człowiek jako osoba funkcjonuje bardzo słabo na płaszczyźnie życia politycznego. Przed nami rysuje się jako konieczne zadanie personalizacja polityki".

Osoba i związana z nią godność jest wartością pożądaną w polityce. Odnosi się ona zarówno do działań politycznych, jak i do polityków, którzy podejmują tę działalność. W polityce poszukuje się jakiegoś fundamentu aksjologicznego. Jako roztropna troska o dobro wspólne obywateli powinna ona łączyć się ze standardami etycznymi. Brak poszanowania zasad etycznych $\mathrm{w}$ życiu społeczno-politycznym sprzyja postrzeganiu polityki jako działalności z gruntu nieuczciwej. W życiu społecznym i politycznym w naszym kraju jest - według opinii Wójcika - coraz więcej negatywnych zjawisk, coraz mniej poszanowania godności człowieka, jego praw, troski o dobro wspólne. Godność i honor, które powinny być cenione w publicznym życiu społecznym, mocno osłabły w nowej rzeczywistości społeczno-politycznej w naszego kraju.

Profesor Wójcik jest bez wątpienia autorytetem naukowym w problematyce samorządu terytorialnego. Także w recenzowanej książce podejmuje tę problematykę $\mathrm{w}$ perspektywie personalistycznej myśli politycznej. Samorząd terytorialny ma wielką wartość społeczną, gospodarczą, patriotyczną i moralną. Przyczynia się on do rozwoju postaw indywidualnych i wspólnotowych, dynamizuje twórczość w wielu dziedzinach życia. „Na skalę państwową zderzenie władzy i wolności ma być łagodzone 
przez instytucję samorządów. Ale musi tu występować doskonała interakcja we współpracy. Władza państwowa spełniająca wszystko na górze i na dole, łatwo popada $\mathrm{w}$ totalitaryzm, a instytucje samorządowe traktujące państwo jako przeciwnika, którego trzeba obalić, czy nawet pokonać, rozbijają państwo na autonomię lokalne. Dlatego państwo musi mieć prymat, bo daje jedność, rozwiązuje problemy fundamentalne, całościowe i centralne, ale korzysta z samorządów jako niezbędnego dopełnienia lokalnego. Zachodzić tu powinna zasada podwójnej pomocniczości: władza centralna ma wspierać autonomie lokalne, a samorządy mają realizować władzę lokalną, a tylko w pewnym zakresie (zadania zlecone) sprawy ogólnokrajowe".

W rozdziale trzecim zatytułowanym Duchowa konstytucja świata Autor wskazuje, jak istotny są wyraziście określone w preambule konstytucji cel i wartości, czyli metazasady ustroju, które nadają nowy charakter oraz dynamizm państwu, porządkując działania władzy państwowej, a także zachowania obywateli. Wykazuje również, że dobrego i sprawiedliwego państwa nie da się zbudować wyłącznie na podstawie prawa stanowionego. Podkreśla wyraźnie, że państwo i prawo powinny wyrastać z powszechnie akceptowanej tradycji i moralności ogólnoludzkiej. Autor postawił sobie za cel ukazanie aktualnego znaczenia konstytucji w związku $\mathrm{z}$ dominującą $\mathrm{w}$ Polsce wiarą katolicką oraz ustosunkował się do wielu wyzwań, jakie stanęły przed społeczeństwem i państwem po 1989 roku, oraz spodziewanych zagrożeń, jakie niesie obecny agresywny, redukcjonistyczny liberalizm, zmierzający do rozmycia wiary religijnej, spłycenia polskiego katolicyzmu i patriotyzmu.

Zdaniem prof. Wójcika konstytucja, aby była szanowana przez katolickie społeczeństwo polskie, powinna opierać prawo na związku z moralnością chrześcijańską, odwołującą się do Boga i respektującą przykazania Boże (Dekalog). Dopiero wzajemny wpływ prawa i moralności może w warunkach Polski odbudować kwestionowane postawy patriotyczne, religijne i niepodległościowe, tak by wytworzyła się elita patriotyczna, a naród stawał się coraz bardziej aktywny i odważny w reformowaniu parlamentu, administracji i wymiaru sprawiedliwości. Autor słusznie uważa, że konstytucja we wstępie powinna wyrażać cel główny oraz szeroki zbiór wartości i ideałów. Dlatego nie może być neutralna, musi opowiadać się wyraźnie za określonymi priorytetami ideowymi. Ustawodawca powinien mieć świadomość zbioru jednoczących wartości i poczucie wspólnego celu. Ma to stanowić deklarację ideałów narodowych 
i religijnych. Dla Polaków to: Bóg, Honor i Ojczyzna, Wiara, Patriotyzm i Praworządność.

Rozdziały czwarty i piąty poświęcono statusowi i znaczeniu religii chrześcijańskiej i Kościołowi katolickiemu w Polsce w dziedzinie życia publicznego, w tym i politycznego. Wychodząc z przesłanek personalizmu prof. Wójcik podkreśla, że moralność w polityce wyrasta $\mathrm{z}$ religii chrześcijańskiej i że jest ona istotnym argumentem wielkiej przyszłości państwa i narodu. W rzeczywistości ma się do czynienia z falami przypływu i odpływu negatywnych nacisków państwa na Kościół katolicki i religię, niekorzystnie wpływa na poczucie bezpieczeństwa obywateli i całego narodu polskiego. W tym kontekście Autor poddał analizie politykę rządzących i opozycyjnych partii politycznych wobec Kościoła, a także uwarunkowania, stan aktualny i perspektywy racjonalnego dialogu państwa i Kościoła. Wiele wskazuje na to, że religijność ludzi może być i jest motorem zmian społeczno-politycznych i technologicznych. Zaczyna się wręcz dostrzegać powrót religii jako źródła wartości do polityki, co jest do pewnego stopnia ważnym politycznym zjawiskiem XXI w.

Omawiając relacje religii i państwa, Autor zwraca uwagę na takie kwestie jak: prawo naturalne i prawo stanowione, realizm i uniwersalizm religii chrześcijańskiej, osoba w państwie społecznym, zmienne relacje państwo-Kościół, Kościół i katolicy wobec naporu neoliberalizmu, ateistyczne dążenia Unii Europejskiej, perspektywy racjonalnego dialogu. Akcentując związki między religią, moralnością i polityką, Profesor wydaje się podzielać pogląd, że można mówić o polityce chrześcijańskiej. Polityka taka to przede wszystkim obecność zasad etyki chrześcijańskiej w życiu społecznym. Wyraża się ona w trosce o dobro wspólne, w określaniu sprawiedliwości i niesprawiedliwości społecznej, w opiece nad ludźmi biednymi i zmarginalizowanymi (opcja preferencyjna na rzecz ubogich) itp. Tak pojętą „politykę" zawierają papieskie encykliki, a jej przekaz jest obowiązkiem Kościoła, w tym i osób duchownych. Inne znaczenie określenia „polityka chrześcijańska” wyrażają konkretne programy polityków i partii powołujących się na inspiracje chrześcijańskie. W rozważaniach prof. Wójcika czytelnik może odnaleźć wiele interesujących konstatacji na ten temat.

W ostatnim rozdziale książki zamieszczono trzy recenzje: artykułu Pawła Tarasiewicza (Spór o naród. Próba typologii stanowisk), książki Jana Waskana (Idea państwa narodowego w myśli politycznej Romana Rybarskiego) i pracy doktorskiej Jolanty Hajder (Społeczno-ekonomiczne implikacje 
polityki prorodzinnej w Polsce). Recenzje prac o tematyce narodowej i rodzinnej w świetle rozumienia myśli personalistycznej dobrze korespondują z głównym nurtem całego opracowania szkicującym personalistyczną myśl polityczną.

Książka Stanisława Wójcika ma przede wszystkim charakter teoretyczny, ale jest ona także swoistym manifestem wskazującym, że odrodzenie naszego życia społeczno-politycznego może i powinno opierać się na personalizmie politycznym. Autor wielokrotnie wskazuje na człowieka jako osobę z przysługującą jej godnością, która jest podstawą wszystkich wartości społecznych i życia całego społeczeństwa. Co więcej, wyraża on $\mathrm{w}$ tekstach zawartych $\mathrm{w}$ recenzowanym opracowaniu osobistą wiarę we wzrastające znaczenie dla Polski i Polaków personalizmu systemowego.

W swoich rozważaniach rozwija twórczo główne tezy personalizmu uniwersalnego teologa polskiego Czesława S. Bartnika, zwłaszcza w odniesieniu do dziedziny życia politycznego (tzw. personalistyczna myśl polityczna). Praca ma charakter interdyscyplinarny, łączy w sobie aspekty politologiczne (także z zakresu politologii religii), z katolicką nauką społeczną (swoista ewangelia społeczna), a także pewne ważne wątki socjologiczne. Tematyka książki jest twórcza, ciekawa i ważna, zwłaszcza w obliczu potrzeby jednoznacznego określenia celu oraz zdiagnozowania zachowań Polaków w czasie obecnym i przyszłym, które wynikają z Dekalogu oraz nowej duchowej konstytucji świata, jaką jest osiem błogosławieństw. Autor dał ujęcia słuszne, poprawne i godne dyskusji, zarówno w naukach o polityce, jak i w katolickiej nauce społecznej.

Janusz Mariański*

* Ks. prof. dr hab. Janusz Mariański, Wyższa Szkoła Nauk Społecznych z siedzibą w Lublinie, e-mail: januszm@kul.lublin.pl 